\title{
Comparison of the obturation density of gutta percha using cold lateral condensation and varying continuous wave of condensation techniques
}

Jamie Michelle Day

West Virginia University

Follow this and additional works at: https://researchrepository.wvu.edu/etd

\section{Recommended Citation}

Day, Jamie Michelle, "Comparison of the obturation density of gutta percha using cold lateral condensation and varying continuous wave of condensation techniques" (2006). Graduate Theses, Dissertations, and Problem Reports. 2376.

https://researchrepository.wvu.edu/etd/2376

This Thesis is protected by copyright and/or related rights. It has been brought to you by the The Research Repository @ WVU with permission from the rights-holder(s). You are free to use this Thesis in any way that is permitted by the copyright and related rights legislation that applies to your use. For other uses you must obtain permission from the rights-holder(s) directly, unless additional rights are indicated by a Creative Commons license in the record and/ or on the work itself. This Thesis has been accepted for inclusion in WVU Graduate Theses, Dissertations, and Problem Reports collection by an authorized administrator of The Research Repository @ WVU. For more information, please contact researchrepository@mail.wvu.edu. 


\title{
COMPARISON OF THE OBTURATION DENSITY OF GUTTA PERCHA USING COLD LATERAL CONDENSATION AND VARYING CONTINUOUS WAVE OF CONDENSATION TECHNIQUES
}

\author{
Jamie Michele Day, D.D.S. \\ Thesis submitted to the \\ School of Dentistry \\ At West Virginia University \\ In Partial Fulfillment of the Requirements \\ For the Degree of
Master of Science
in
Endodontics \\ C. Russell Jackson, D.D.S., M.S., Chair \\ Michael Bagby, D.D.S., M.S., PhD \\ Louise T. Veselicky, D.D.S., M.S.D.
}

Department of Endodontics

Morgantown, West Virginia

2006

Keywords: Obturation Density, Continuous Wave of Condensation Copyright 2006 Jamie M. Day 


\title{
ABSTRACT \\ COMPARISON OF THE OBTURATION DENSITY OF GUTTA PERCHA USING COLD LATERAL CONDENSATION AND VARYING CONTINUOUS WAVE OF CONDENSATION TECHNIQUES
}

\author{
Jamie Michele Day, D.D.S.
}

This study compared the density of gutta percha when using cold lateral condensation (CLC) and continuous wave of condensation (CWC) under varying temperature and plugger depths. Seventy acrylic blocks were instrumented. The blocks were weighed and assigned to seven groups. Group 1 was obturated with CLC. The remaining six groups were obturated with CWC. Groups 2-4 were obturated by advancing the plugger to $3 \mathrm{~mm}$ short of the working length at $100^{\circ} \mathrm{C}, 200^{\circ} \mathrm{C}$, and $300^{\circ} \mathrm{C}$, respectively, and then backfilled. In groups 5-7 the plugger was advanced to $5 \mathrm{~mm}$ short of working length. The blocks were weighed again after obturation. Data were analyzed using a one-way ANOVA and Tukey's tests. Results indicated a significantly greater density of gutta percha when using CWC compared to CLC and when the plugger was advanced to $3 \mathrm{~mm}$ short of working length ( $\mathrm{p}<.05)$. No significant differences were noted between the three different temperatures $(p>.05)$. 


\section{DEDICATION}

For Mom, Dad and Josh

No support could ever compare to what I have received.

Thanks. 


\section{ACKNOWLEDGEMENTS}

Thanks to Dr. Russ Jackson for giving me the opportunity to become an endodontist and for guidance along the way.

Thanks to Drs. Bagby and Veselicky for help and support during my thesis from start to finish.

Thanks to Marilyn, Cathy and Gina for all of their help in everything and for wonderful friendships.

Thanks to Drs. Lora Ford and Pam Harrington for making the first year fun and for helping us learn the ropes.

Thanks to Drs. Nic Taylor and Kent McBride for all of the laughs, memories and for never letting any moment become a dull one. I really value the friendships we have developed.

Thanks to Dr. Becky Tolley for being there day in and day out when I needed to vent about something.

Finally, thanks to Dr. Rodney Southern. Where should I begin? I would not have wanted to share this experience with anyone else. No other person can appreciate what the last two years have been like but the two of us. It is truly a special thing to be thrown into a program with a complete stranger only to leave it two years later with one of the best friends you will ever have. There are too many things to attempt to thank you for them all. But, you know I appreciate everything you have ever done and continue to do for me. 


\section{TABLE OF CONTENTS}

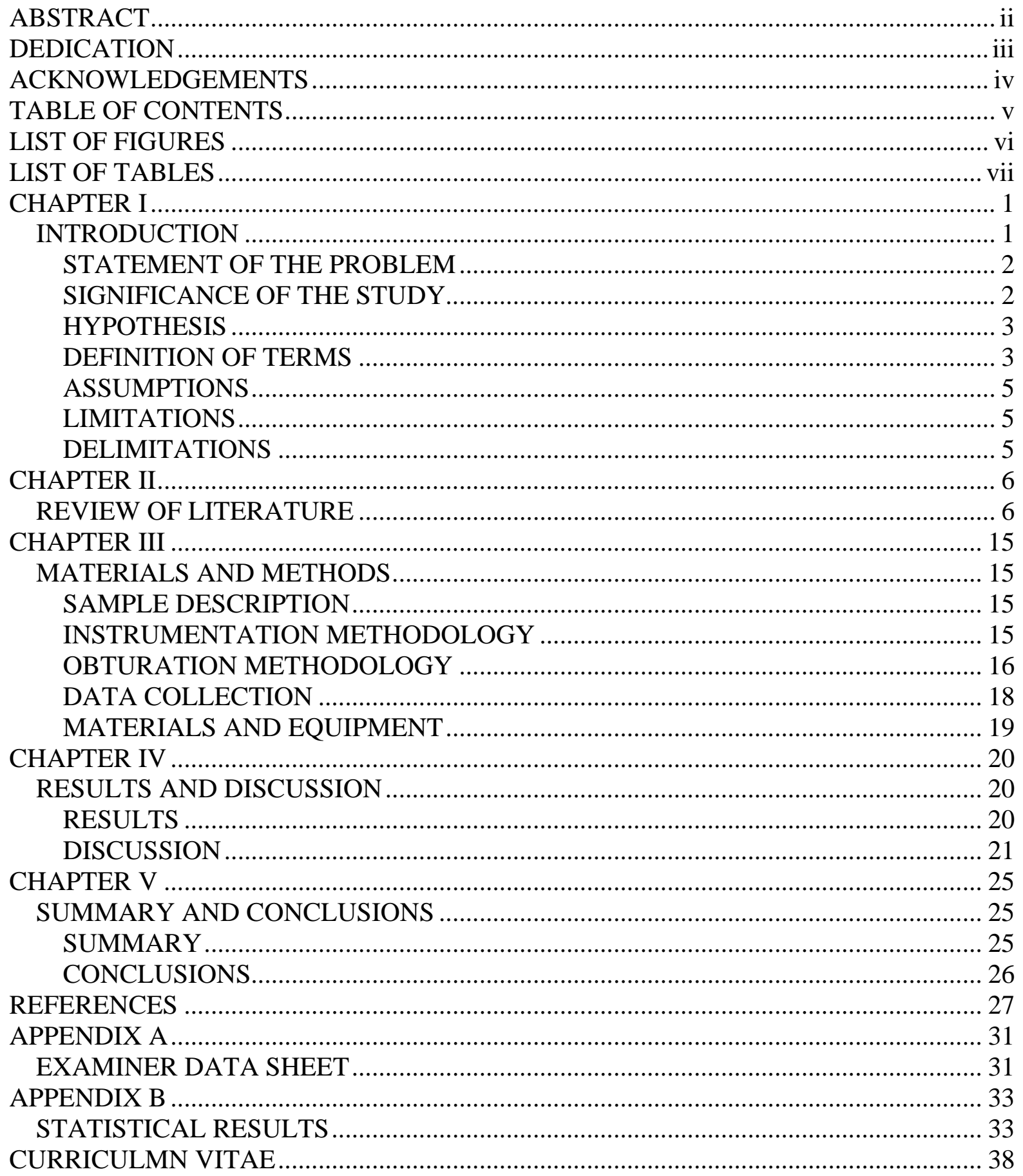




\section{LIST OF FIGURES}

Figure 1. Sample Acrylic Block .......................................................................................................... 15

Figure 2. Blinder ............................................................................................................................ 18

Figure 3. Comparison of Gutta Percha Mass between Groups ............................................. 21 


\section{LIST OF TABLES}

Table 1. Research Design .................................................................................................................... 16

Table 2. Gutta Percha Mass between Groups ............................................................. 20 


\section{CHAPTER I INTRODUCTION}

Major advancements have been made in the techniques used to obturate root canal anatomy during endodontic therapy over the last half century. Many of these improvements have come about, in part, due to improved techniques to the cleaning and shaping stage of root canal therapy. The cleaning and shaping procedure allows the clinician to produce a canal that is cleaned mechanically and chemically and shaped to the optimal configuration to accept obturation. The obturation procedure attempts to eliminate all routes of leakage that may occur from the oral cavity and seals in any other irritants that could not fully be removed during the preparation of the canal.

The continuous wave of condensation obturation technique developed by Dr. L. Stephen Buchanan has shown much promise in three-dimensional filling of the root canal system. (1) During this procedure, gutta percha is heated with one continuous wave of heat to facilitate movement of gutta percha and sealer into even the smallest of canal intricacies. The mass of apical gutta percha is then compacted vertically to produce a dense apical fill.

With the increasing popularity of this technique, come many concerns about the potential complications that can occur when periradicular temperatures rise above acceptable conditions. Gutta percha is still the most widely used and accepted obturation material because of its biocompatibility, inertness, dimensional stability, compactibility, plasticity when heated and ease of removal is retreatment becomes necessary. (2) However, to heat 
gutta percha to the state necessary for a complete three-dimensional fill, high and prolonged heat is recommended.

This study was designed to compare the density of gutta percha produced under varying temperatures and plugger depth penetration of a System B Heatsource plugger. The possibility exists that a lower temperature setting and less penetration into the canal with a heated instrument could produce equal fill of the canal system and reduce possible complications that may occur with higher temperatures.

\section{STATEMENT OF THE PROBLEM}

There have been no studies to evaluate the density of gutta percha under varying temperature conditions and plugger depth of the System B Heatsource when utilizing the continuous wave of condensation obturation technique.

\section{SIGNIFICANCE OF THE STUDY}

Cleaning and shaping of a root canal system is critical in the ability to properly obturate the anatomy of the system. New techniques in cleaning and shaping have led to improved techniques in obturation as well. The continuous wave of condensation technique is a warm vertical technique that has shown promise in more complete three-dimensional filling of canal systems. However, the technique produces potentially high temperatures that may have damaging implications to the periradicular tissues. The results of this study could suggest the proper temperature setting and depth of plugger penetration of the System B Heatsource for optimal obturation when utilizing the continuous wave of condensation obturation technique. 


\section{HYPOTHESIS}

The null hypotheses are: (1) There is no significant difference in the mass of obturation material between the lateral condensation group (control group) and the continuous wave of condensation groups (experimental groups). (2) There is no significant difference in the mass of obturation material among the experimental groups when comparing plugger temperature and depth of plugger penetration of the System B Heatsource when utilizing the continuous wave of condensation technique.

\section{DEFINITION OF TERMS}

Backfilling- The injection and/or compaction of gutta percha into a canal after creation of an apical seal.

Cold lateral condensation- An obturation technique which involves the placement of sealer and a fitted master gutta percha point, which is laterally compacted by a spreader to make room for additional accessory gutta percha points.

Continuous wave of condensation (CWC)- A technique of warm vertical gutta percha compaction developed by L. Stephen Buchanan, D.D.S. This technique utilizes a wave of continuous heat from an electronic heat source to warm the gutta percha during apical compaction.

Crown-down preparation- A technique of canal preparation, which enlarges the coronal portion of the canal initially. The canal is enlarged in a step-wise fashion from the coronal orifice towards the apical foramen with progressively smaller files until the desired length is achieved. 
Downpacking- The compaction of incremental segments of heat-softened gutta-percha to create an apical plug.

Master apical file (MAF)- The largest file used to the full working length of the completely prepared root canal.

Obtura II- A device used to expel warm gutta percha into the root canal space.

Obturation density- The amount of compacted gutta percha in the canal space.

Plugger- A smooth, flat-ended and slightly tapered metal instrument designed to compact materials vertically within a prepared root canal.

Reference point- A repeatable landmark at the top of the acrylic block used to maintain working length.

Rotary instrumentation- A technique of canal instrumentation, which utilizes an engine driven handpiece to rotate endodontic files in a 360-degree clockwise direction.

Spreader- A smooth, pointed, slightly tapered metal instrument designed to compact materials within a prepared root canal.

System B Heatsource- An electronic device, which provides the delivery of a heated plugger type instrument in the canal. The System B heating units have tapered plugger units that can be sized to fit most canal spaces.

Warm vertical condensation- An obturation technique that utilizes a heated plugger or an electronic heat source instrument. Gutta percha is burned off with an instrument and then immediately compacted apically with a plugger.

Working length- The length from the top of the acrylic block to the canal terminus. 


\section{ASSUMPTIONS}

(1) Acrylic blocks can be satisfactorily instrumented and obturated to be evaluated for density of obturation material. (2) Density of obturation material is a good model in evaluating complete fill of the root canal system.

\section{LIMITATIONS}

(1) This in-vitro study attempted to represent root canal obturation concepts that can be applied to a clinical setting; however, results may vary from in-vivo conditions. (2) Heat produced from the System B could potentially alter anatomy of the acrylic blocks.

\section{DELIMITATIONS}

(1) Acrylic blocks were used to provide least amount of variability possible. (2) All simulated canals had the same degree of curvature. (3) All canals were worked to an MAF of \#35. (4) All blocks were instrumented, obturated, and weighed by the principal investigator. (5) Sealer was not used so only gutta percha mass could be studied. (6) Any block with obvious signs of charring or melting of the acrylic after use of the System B Heatsource was eliminated. 


\section{CHAPTER II REVIEW OF LITERATURE}

The three-dimensional obturation of the root canal system is widely accepted as a key factor for successful endodontic therapy. (3) Studies have come to show that one can achieve a more complete root canal filling by utilizing a warm obturation technique. Techniques and armamentarium have evolved greatly to allow practitioners a more efficient, reliable and predicable way to incorporate this type of obturation into their practices. Schilder described the warm vertical obturation technique in 1967 and since then, modifications to this technique have flooded the endodontic literature. (4) Regardless of the way endodontic obturation procedures are completed, the objectives have remained the same.

The purposes of obturating the prepared root canal space are as follows: (1) to eliminate all avenues of leakage from the oral cavity and periradicular tissues into the root canal system, and (2) to seal within the system any irritants that cannot be fully removed during the cleaning and shaping procedures. These objectives recognize the importance of microbial irritants and pulp tissue degeneration products as a prime cause for pulpal decline and that failure to remove these factors adequately will cause continued irritation from contamination and subsequently root canal therapy failure. (5) Therefore, three-dimensional obturation is of utmost importance when evaluating a tooth following root canal therapy completion.

Cold lateral condensation is the foundation obturation technique that is understood by students and practitioners alike since is has been the technique in which most all dental 
students have been taught in the past century. It is typically the technique used to compare all obturation techniques against in studies examining obturation procedures. It is not accepted that this is necessarily a superior technique, but rather that it is reliable, reproducible and understandable to most clinicians. (2)

The cold lateral condensation procedure involves cleaning and shaping the root canal system to produce a conical shape that forms a continuous taper from its coronal aspect to the apex. A master gutta percha cone is fitted to place with sealer and successive accessory cones are inserted alongside the master cone. Due to the funnel shape of the canal, a spreader is easily inserted making room for each of the accessory points to be placed. During this procedure, the gutta percha is compacted into a dense mass that fills the root canal space. (6)

Before any type of obturation procedure can be successfully accomplished, one must first shape and clean the canal with the objectives of three-dimensional obturation in mind. The shaping procedure removes the bulk contents from the canal system and creates the smooth, tapered opening to the terminus. Shaping also facilitates cleaning and obturation by removing restrictive dentin and allowing effective volumes of irrigants and instruments to work deeper and more quickly into the entire system. With the invention of greater taper files, cleaning and shaping has become more efficient especially in the coronal third of the root canal allowing these objectives to be more easily met. Any clinician must realize that shape is critical not only for effective cleaning, but also for three-dimensional obturations. Consistently producing optimal shape will continuously produce well-obturated canals and become the foundation in a clinician's endodontic success. (7) 
Gutta percha is the most commonly used obturating material in endodontics. Dental gutta percha contains about $20 \%$ gutta percha, $66 \%$ zinc oxide, $11 \%$ heavy metal sulfates, and 3\% waxes and resins. (8) It exists in two distinct crystalline forms, a beta form and an alpha form, which can be converted into each other. The alpha form comes from the natural tree product and the beta form is that which is processed and used in root canal systems. During heating and cooling, phase transitions occur. At around $46-52^{\circ} \mathrm{C}$, the crystalline structure changes from the beta phase to alpha phase and ultimately into an amorphous melt at around $56-62^{\circ}$ C. (5) Normal cooling returns it to a beta phase as temperatures fall to around $42-40^{\circ}$, however a rapid decrease in volume occurs as this cooling takes place. Shrinkage can be prevented if it is not heated above $45^{\circ} \mathrm{C}$, however a temperature of $64^{\circ} \mathrm{C}$ is necessary to soften gutta percha for warm techniques. Therefore, it is necessary to maintain vertical pressure in all warm gutta percha techniques to compensate for the volume changes that occur as cooling takes place. (9) Newer alpha form gutta percha has been marketed for dental use under trade names such as Thermafil, Densfil and Microseal. These have a lower melting point, lower viscosity and will flow with less pressure and stress while exhibiting an increase in tackiness to form a more homogenous fill. They also exhibit less shrinkage, but are technique sensitive procedures. (10)

The essentials of warm vertical compaction have been around for almost a century, but Dr. Herb Schilder popularized this technique in the 1960's and it now is commonly called the Schilder technique. This technique utilizes a system of varying sized pluggers to burn off and compact warm gutta percha apically. A master cone is selected, fit for size, coated with sealer and inserted into the root canal. The largest plugger is used to burn off the coronal portion of the gutta percha with immediate apical compaction. This process continues with 
smaller pluggers until $5.0 \mathrm{~mm}$ of gutta percha remains in the root canal. At this stage the space can be left if a post space is required, or backfilled with another technique. During this process, gutta percha is forced into canal irregularities. (4)

In 1986, Buchanan introduced the continuous wave of condensation technique. (1) This technique, utilizes an electrical heat source (i.e. System B) with a heated plugger delivery unit, standard gutta percha and sealer. Once cleaning and shaping have been accomplished, a heated plugger delivery unit is selected based on the canal size and configuration and pre-fitted to make certain the plugger can advance to between $4-5 \mathrm{~mm}$ from the working length. Once this has been accomplished, a gutta percha cone is selected and fit to the working length. The heated plugger is used to sear off the gutta percha at the canal orifice and a plugger is used to compact this gutta percha. The plugger is then activated and introduced into the canal at $200^{\circ} \mathrm{C}$ to about $3-4 \mathrm{~mm}$ short of its binding point before the plugger is deactivated. The plugger will continue to advance to one mm short of its binding point at which firm apical pressure should be maintained for 10 seconds. This action compensates for any shrinkage that may occur during cooling. While still maintaining pressure, the plugger is activated with a one second burst of heat and the plugger is quickly removed. With a smaller plugger, it is confirmed that the apical mass of gutta percha has not become dislodged by maintaining firm apical pressure. At this point the space can remain for a post space, or backfilled. (11) Buchanan asserts that it is not necessary to advance the plugger further than 4-5 mm from the working length because the gutta percha is heated 4-5 mm past the tip of the plugger unit. (12) Recently, Bowman and Baumgartner found that there is better gutta percha flow into lateral grooves when the plugger is advanced to $3 \mathrm{~mm}$ from working length. (13) 
There have been many studies comparing these two warm vertical techniques to one another and to cold lateral condensation. Many advantages have been found when using a warm obturation technique. Blum et. al. used a force analyzer device and found a decrease in the wedging effect for warm vertical compaction compared to lateral condensation. This may have an effect on the fracture resistance of teeth during root canal therapy. (14)

Studies have overwhelming shown that warm vertical obturation techniques accomplish a more complete three-dimensional filling than cold techniques. A statistically significant greater number of simulated lateral canals were obturated when using the System B plus the Obtura II as compared to cold lateral or the Obtura II alone. (15) Warm vertical compaction using the continuous wave condensation technique in acrylic blocks resulted in a greater gutta percha fill by mass compared with standard cold lateral. (16) In a study comparing three obturation techniques, the warm obturation techniques had significantly more gutta percha in lateral canals. (3) The percentage of gutta percha filled canal area using warm gutta percha was greater than that of cold gutta percha in oval canals. (17)

Jacobson et. al. studied the microleakage of the continuous wave of condensation technique and found that microbial coronal leakage occurs more quickly using lateral condensation than with the System B continuous wave of condensation and Obtura II backfill. (18) When using the System B, Nelson et al. found a 23.97\% increase in the weight of gutta percha after one heat application compared to standard cold lateral condensation. After a second application of heat, an additional of $2.59 \%$ increase was produced. The results indicate that warm techniques using the System B result in a denser gutta percha fill by weight when compared to standard cold lateral. (19) Under laboratory conditions, Gilhooley et. al. found that warm gutta percha had a better sealabilty as assessed with a dye 
penetration method than cold lateral condensation. (20) Wong et. al. found that warm vertical condensation was significantly better at reproducing canal anatomy than cold lateral condensation. (21) The results of these studies indicate the potential for a more complete dense fill when using a warm obturation technique. Eldeeb found a correlation between radiographic density and leakage especially in the middle one third of the root. (22) Echoing this, Chugal et. al. found the risk of failure to be higher for a poor or fair density of obturation than for a good density for any type of periradicular diagnosis prior to treatment.

Although most studies find warm vertical a superior technique, not all studies have found this to be true. Benner et. al. found no difference in leakage between cold lateral and warm vertical condensation. (24) Larder et. al. found that there was no significant difference in cold lateral and warm vertical condensation at reproducing canal anatomy. (25)

There are some significant disadvantages that accompany the use of warm vertical techniques as well. First, when filling a canal system with a warm technique, care must be taken to avoid excessive extrusion of material through the apex. Root canals filled with warm gutta percha had significantly more extrusion of sealer and gutta percha than canals filled by lateral condensation. (26) Many of the newer techniques allow this factor to be more controlled and predictable. Furthermore, if the root canal is optimally shaped, an environment is created to force excess gutta percha in a coronal direction instead of through the apex.

Another concern is the heat that is generated when using these techniques. Eriksson and Albrektsson found that in a rabbit tibia, a temperature of $53^{\circ} \mathrm{C}$, i.e. below the 
denaturation point of alkaline phosphatase, caused an irreversible bone injury, after which healing occurred from the surrounding tissues. (27) It is generally accepted that a temperature of $47^{\circ} \mathrm{C}$ is the critical temperature when permanent damage to the supporting structures of the tooth root may occur. This is about a $10^{\circ} \mathrm{C}$ rise from average temperature. (28) Studies by Fors et. al. and Gutmann et. al. agree that $10^{\circ} \mathrm{C}$ above normal body temperature is the critical level where irreversible damage to the periodontium is of concern. $(29,30)$ Studies are conflicting in whether or not using warm techniques allow temperatures to rise above these critical levels. Lee used a thermocouple $2 \mathrm{~mm}$ below the cementoenamel junction to transfer heat to a digital thermometer and found that the System $\mathrm{B}$ had $<10^{\circ} \mathrm{C}$ rise in all experimental teeth. The Touch n' Heat electronic heating device demonstrated a rise of $<10^{\circ} \mathrm{C}$ in all teeth expect mandibular incisors, and a flame-heated carrier demonstrated $>10^{\circ} \mathrm{C}$ in all experimental teeth. (31) Lipiski studied the root surface temperature rise during root canal obturation using the System B and continuous wave of condensation technique with an infrared thermal imaging camera. He found that the System B produced temperature changes on the outer root surfaces, which, in the case of teeth with relatively thin dentinal walls, can reach high values. In the case of mandibular central incisors, temperatures elevated more than $10^{\circ}$ C. $(32)$

Floren et. al. found that temperatures above $250^{\circ} \mathrm{C}$ as those recommended for removal of plastic obturation carriers during endodontic retreatment has the potential to cause root surface temperatures to rise above $10^{\circ} \mathrm{C}$. Using 10 thermocouples at one $\mathrm{mm}$ increments along the tooth, it was found that a site $5 \mathrm{~mm}$ from the apex had the highest increase in surface temperature when the plugger was inserted to a depth of $3 \mathrm{~mm}$ short of working length. This temperature exceeded the critical value for over one minute indicating 
that damage could occur. (33) Sweatman et. al. disputed these findings and found that at no time did the external surface of the root exceed an increase of $10^{\circ} \mathrm{C}$ at any thermocouple level even when the plugger was set to a temperature of $300^{\circ} \mathrm{C}$. (34) Venturi et. al. agreed that using the System B Heatsource ${ }^{\mathrm{TM}}$ has negligible effects on outer root temperature. (35)

With conflicting evidence in the literature, it is safe to say the care must be taken when utilizing any warm technique and the lowest temperature possible should be used. It is uncertain how these studies convert to in vivo conditions, however, it is certain that the potential for complications can occur if temperatures rise above that critical level.

With this in mind, a few studies have attempted to find the lowest temperature to achieve clinical acceptable obturation results. The depth of plugger penetration has also been studied. Jung et. al. used acrylic blocks with artificially created oval canals and obturated them with the continuous wave of condensation technique at $100^{\circ}, 200^{\circ}$ and $350^{\circ} \mathrm{C}$ temperature settings and at plugger depth penetration of $4 \mathrm{~mm}$. He also went to $2 \mathrm{~mm}$ from the apex with a plugger set at $200^{\circ} \mathrm{C}$. Plugger temperatures within the range used did not affect the percentage of gutta percha (PGP) filled area, however, the penetration depth of the plugger was significantly related to the PGP. (36) Yared et. al. found similar results. He found that deeper plugger penetration showed significantly less apical leakage. (37) Wu et. al. found an average of $96.1 \%$ gutta percha filled area when heat was applied $2 \mathrm{~mm}$ short of working length compared to $87 \%$ when applied to only $4 \mathrm{~mm}$ short of working length. (38) Guess et. al. obtained best results with a plugger depth of 3.5 to $4.5 \mathrm{~mm}$ from the working length. (39) 
This study attempted to find the lowest temperature setting and proper depth of plugger penetration of a System B plugger when using the continuous wave of condensation technique. An examination of obturation density was accomplished using acrylic blocks with simulated root canal anatomy. While this was an in vitro study, all obturation concepts were followed as they apply in a clinical setting. 


\section{CHAPTER III \\ MATERIALS AND METHODS}

\section{SAMPLE DESCRIPTION}

Acrylic blocks simulating root canal anatomy were obtained from Kilgore

International for this study. (see Figure 1.) All of the blocks had a 30-degree canal curvature. They were chosen to minimize variability between the samples. Each block was instrumented in the same manner and to the same master apical file.

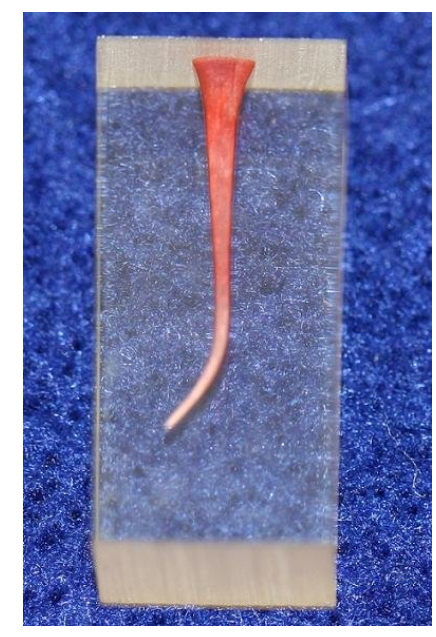

Figure 1. Sample Acrylic Block

\section{INSTRUMENTATION METHODOLOGY}

A standard instrumentation procedure was carried out on every block. An ISO \#10 hand file was inserted into the canal to determine working length. When the tip of the file became visible at the terminus of the canal, the stopper was set to the reference point and measured. This was considered the actual length of the canal. The exact working length was determined by subtracting $1.0 \mathrm{~mm}$ from the measured actual length. 
Once working length had been established, Gates Glidden burs \#2, \#3, and \#4 were used to enlarge the coronal half of the canal. Irrigation with at least $3.0 \mathrm{ml}$ of water was used to flush debris from the canal between Gates Glidden burs and files. ISO ProFile rotary files were used in a crown-down preparation. A \#40 file was used to prepare the top two-thirds of the canal followed by a \#35 file to the working length. Once instrumentation was complete, each block was given a final irrigation and dried with paper points. At this point each block was randomly assigned to a group with 10 blocks in each group. Initial weight was taken with a digital scale and recorded to the nearest $.0001 \mathrm{~g}$. This weight was referred to as the weight of block after instrumentation.

Table 1. Research Design

\begin{tabular}{|c|c|c|c|}
\hline $\begin{array}{c}\text { Assigned } \\
\text { Group }\end{array}$ & $\begin{array}{c}\text { Obturation } \\
\text { Technique }\end{array}$ & $\begin{array}{c}\text { System B Plugger } \\
\text { Temperature }\end{array}$ & $\begin{array}{c}\text { System B Plugger } \\
\text { Depth from WL }\end{array}$ \\
\hline $\mathbf{1}$ & Cold Lateral & N/A & N/A \\
\hline $\mathbf{2}$ & CWC & $100^{\circ} \mathrm{C}$ & $3 \mathrm{~mm}$ \\
\hline $\mathbf{3}$ & CWC & $200^{\circ} \mathrm{C}$ & $3 \mathrm{~mm}$ \\
\hline $\mathbf{4}$ & CWC & $300^{\circ} \mathrm{C}$ & $3 \mathrm{~mm}$ \\
\hline $\mathbf{5}$ & CWC & $100^{\circ} \mathrm{C}$ & $5 \mathrm{~mm}$ \\
\hline $\mathbf{6}$ & CWC & $200^{\circ} \mathrm{C}$ & $5 \mathrm{~mm}$ \\
\hline $\mathbf{7}$ & CWC & $300^{\circ} \mathrm{C}$ & $5 \mathrm{~mm}$ \\
\hline
\end{tabular}

\section{OBTURATION METHODOLOGY}

Each block was obturated according to its assigned group. No sealer was used in this study to allow only the gutta percha mass to be measured.

The cold lateral condensation group acted as the control group in this study. A .04 taper master gutta percha cone was fit to the working length with the help of a gutta gauge and a \#15 scalpel blade. Once fit to place, a hand spreader with a rubber stopper set $1 \mathrm{~mm}$ short of working length was inserted and confirmation was made that it would go to that 
depth. A \#25 .02 taper accessory gutta percha cone was placed and the cold lateral condensation procedure continued until the spreader could not penetrate more than $4 \mathrm{~mm}$ into the canal from the reference point. The System B was used to sear off the cones from the canal orifice and a large Buchanan hand plugger was used to condense the softened gutta percha at the orifice. A \#15 scalpel blade was used to trim the gutta percha flush to the top of the block.

The Continuous wave of condensation groups were the experimental groups in this study. A System B plugger was chosen and placed into the canal to confirm it would advance to the needed depth. A .06 taper master gutta percha cone was fit to the working length with the help of a gutta gauge and \#15 scalpel blade. Once fit to place, the System B was used to sear off the cone at the canal orifice and a large Buchanan hand plugger was used to condense the softened gutta percha at the orifice. The downpack procedure varied according to the assigned experimental group. The temperature was set at $100^{\circ} \mathrm{C}$ for groups 2 and $5,200^{\circ} \mathrm{C}$ for groups 3 and 6 , and $300^{\circ} \mathrm{C}$ for groups 4 and 7 . In groups $2-4$, the plugger was allowed to advance to $3 \mathrm{~mm}$ short of the working length. In groups 5-7, the plugger was allowed to advance to $5 \mathrm{~mm}$ short of the working length. The downpack procedure in all groups consisted of activation of the plugger for no more than 3 seconds as it advanced to within 3-4 $\mathrm{mm}$ of the intended depth before it was deactivated. The plugger was allowed to continue to advance to its intended depth. When that depth had been reached, apical pressure was maintained for 10 seconds. A separation burst of heat was applied to the plugger and quickly removed from the canal. A small Buchanan hand plugger was used to condense the softened gutta percha and to confirm that it had not been dislodged. 
At this point, the canal was ready to be backfilled with the Obtura II. The Obtura II gun was set to a temperature of $150^{\circ} \mathrm{C}$ and the needle was inserted into the canal and allowed to make contact with the gutta percha mass. Flow 150 gutta percha was then extruded into the canal as the gun was allowed to back its way out of the canal. The space was filled in one increment of the gun and a large Buchanan hand plugger was used to condense the softened gutta percha at the canal orifice. A \#15 scalpel blade was used to trim the gutta percha flush to the top of the block.

All procedures were carried out with the block placed in a custom-made polyvinyl sleeve, a blinder, so that the investigator could not visualize the canal during the procedure and to better simulate a clinical setting.

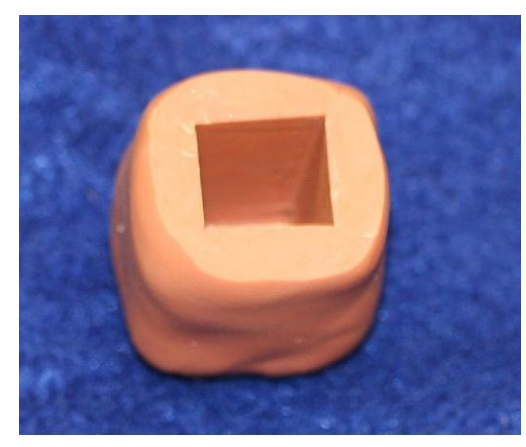

Figure 2. Blinder

\section{DATA COLLECTION}

Once all blocks had been obturated, final weight measurements were taken and recorded to the nearest $.0001 \mathrm{~g}$. This weight was referred to as weight of block after obturation. Mass of gutta percha was calculated with the equation:

Mass $=($ weight of block after obturation $)-($ weight of block after instrumentation $)$ 
Since all of the blocks were worked to the same size, it is assumed that the volume of space obturated is the same in every block; therefore, any increase in mass would also be an increase in density.

\section{MATERIALS AND EQUIPMENT}

- 70 acrylic blocks (Kilgore International, Coldwater MI)

- Dentsply/Tulsa Dental Electric rotary motor and handpiece (Tulsa Dental, Tulsa $\mathrm{OK})$

- Profile ISO .06 rotary files (Tulsa Dental, Tulsa OK)

- Gates Glidden burs \#2-4 (Dentsply Maillefer, Tulsa OK)

- Flexofile ISO endodontic files (Dentsply Maillefer, Tulsa OK)

- Monojet endodontic irrigation syringes (Sherwood Medical, St. Louis MO)

- Absorbent paper points \#35 (Dentsply Maillefer, Tulsa OK)

- Gutta percha points .02, .04, and .06 taper (Dentsply Maillefer, Tulsa OK)

- Gutta gauge (Dentsply Maillefer, Tulsa OK)

- \#15 scalpel blade (Miltex, York PA)

- cotton forceps (Hu-Friedy, Chicago, IL)

- System B Heatsource with pluggers (Analytic Technologies/Sybron Endo, Orange CA)

- Obtura II (Obtura Spartan Corporation, Fenton MO)

- Obtura Flow 150 gutta percha (Obtura Spartan Corporation, Fenton MO)

- Endodontic hand spreader (Miltex, York PA)

- Buchanan hand pluggers (Sybron Endo, Orange CA)

- digital balance (American Scientific Products) 


\section{CHAPTER IV RESULTS AND DISCUSSION}

\section{RESULTS}

The data collected were analyzed using a one-way ANOVA and Tukey's HSD tests. (see appendix A for raw data.) Table 2. summarizes the mean weight and standard deviation between the various groups. Figure 1. displays the mean weight and standard deviation in graph form.

The results did not support all of the null hypotheses. A significantly greater mass of gutta percha was found when using the CWC technique compared to the control CLC group $(\mathrm{p}<0.05)$. No significant difference was found between the three different temperature settings ( $p>0.05)$. However, plugger depth penetration was found to be significantly different with the $3 \mathrm{~mm}$ experimental group producing a greater mass of gutta percha than the $5 \mathrm{~mm}$ group $(\mathrm{p}<0.05)$

Table 2. Gutta Percha Mass between Groups

\begin{tabular}{|c|c|c|c|c|}
\hline Group & $\begin{array}{c}\text { Mean Weight of } \\
\text { Instrumented Block (g) }\end{array}$ & $\begin{array}{c}\text { Mean Weight of } \\
\text { Obturated Block (g) }\end{array}$ & $\begin{array}{c}\text { Mean Weight of } \\
\text { Gutta-Percha (g) }\end{array}$ & SD (x10 $\left.{ }^{-3}\right)$ \\
\hline 1 & 3.8163 & 3.8418 & 0.0254 & 4.3012 \\
\hline 2 & 3.8129 & 3.8601 & 0.0472 & 5.4005 \\
\hline 3 & 3.8129 & 3.8588 & 0.0459 & 3.7818 \\
\hline 4 & 3.8052 & 3.8521 & 0.0469 & 5.2522 \\
\hline 5 & 3.8109 & 3.8548 & 0.0439 & 4.5578 \\
\hline 6 & 3.8100 & 3.8526 & 0.0426 & 4.2303 \\
\hline 7 & 3.8101 & 3.8521 & 0.0420 & 3.6482 \\
\hline Mean $\left.^{-3}\right)$ & 3.8112 & 3.8532 & 0.0420 & \\
\hline SD(x10 & 3.4323 & 5.9943 & 7.5814 & \\
\hline
\end{tabular}




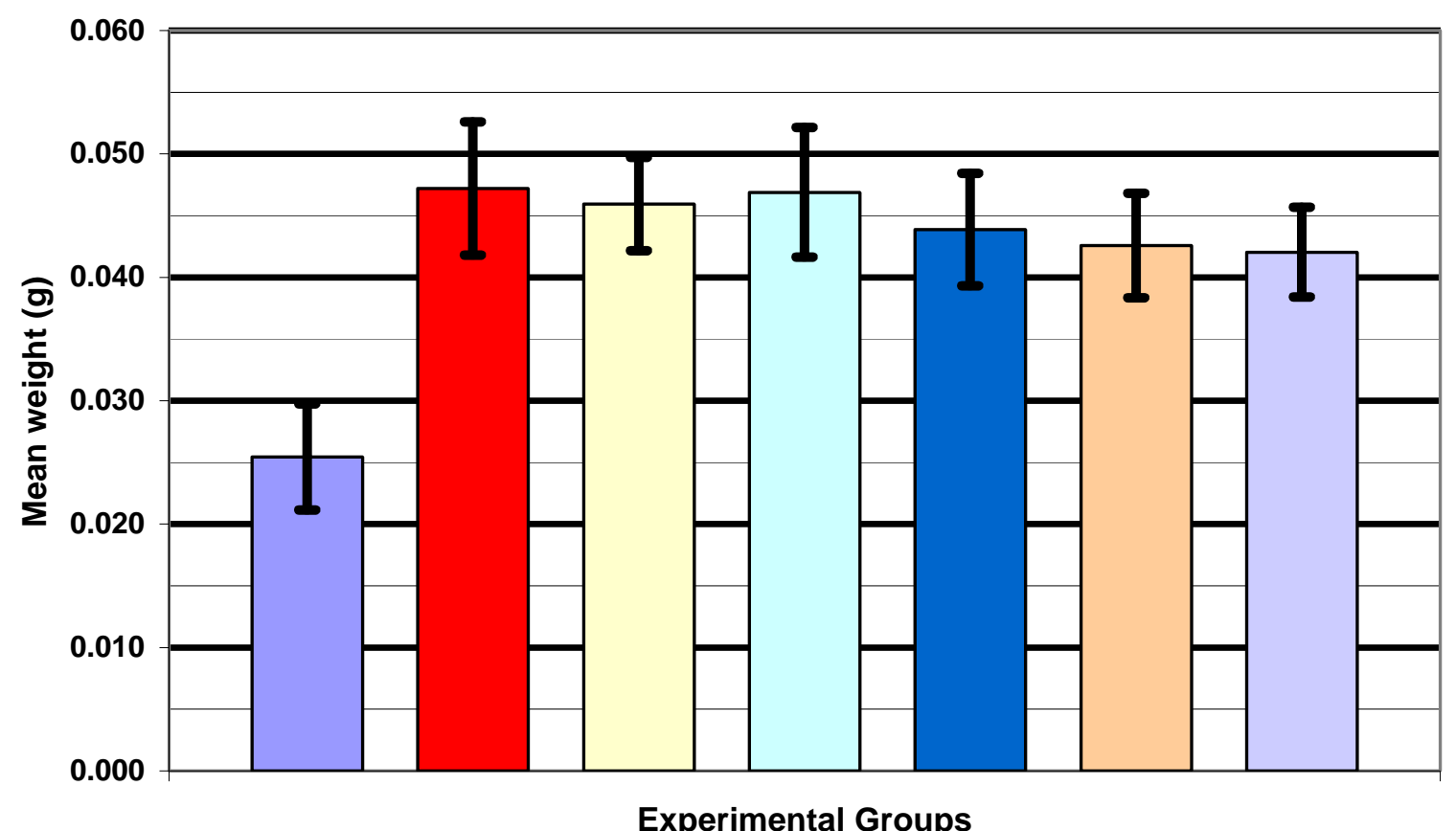

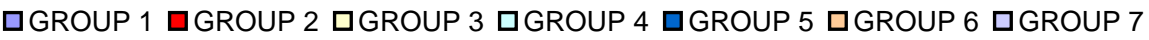

Figure 3. Comparison of Gutta Percha Mass between Groups

\section{DISCUSSION}

The advancements in cleaning and shaping techniques have facilitated the use of many new obturation techniques. Although we can never thoroughly eliminate all bacteria from the canal system, nickel-titanium rotary instrumentation along with more effective irrigation of the internal tooth anatomy give us much more predictability in root canal therapy. Ideally, the obturation of a root canal system should barricade any remaining bacteria or debris that remains in canal intricacies that are untouched by our chemical and 
mechanical debridement. In order to accomplish this with consistent results, we must be certain that we are accomplishing the most complete fill of the root canal system.

Although CLC has been the "gold standard" in root canal obturation for nearly a century, newer techniques are proving to be superior in accomplishing our objectives of a more complete root canal filling. In the years past, it has been thought that the CLC technique was, in fact, a conceptually inferior technique; however, it was the only technique that could produce reliable and reproducible results. (2) This is no longer true with the introduction of greater taper files and techniques that are more understandable, reliable and reproducible to most any prudent clinician.

With the popularization of warm vertical techniques we must be aware of the potential complications that can occur when we subject the periradicular tissues to such high temperatures. (32) Although studies are conflicting as to the clinical rise in temperature that may occur during these procedures, the possibility does exist that these techniques can produce a rise in temperature above the $47^{\circ} \mathrm{C}$ temperature that is agreed to be the critical point where permanent damage may occur to the supporting structures of a tooth. $(28,29,30)$ This study explored the alternative of using much lower temperatures to accomplish the same three-dimensional fill of the root canal system when using the continuous wave of condensation technique.

The methods for carrying out this study were based as much as possible on the clinical techniques and procedures we use everyday. The design, using acrylic blocks, has been used in similar studies looking at other obturation techniques. Several other researchers have carried out similar studies using acrylic blocks with much success. $(16,19,36,40)$ The blocks provided a means of minimizing variability between canals. Each block was 
instrumented to the same size, therefore the volume of each canal should be the same. All instrumentation and obturation was completed by the principle investigator to decrease interexaminer error. During all procedures, the investigator was unable to see the canal as it was placed in a custom-made polyvinyl sleeve, a blinder, to simulate a clinical case. Once obturation was complete, the blocks were removed from the blinder and inspected for any sign of damage and distoration that may have occurred during the procedure. No sign of alteration was noted on any block. Likewise, each block visually demonstrated a complete fill along the entire canal length.

This study was in agreement with a recent study by Lea et. al. that using the CWC technique produces a greater density of gutta percha than cold lateral condensation. (16) The results also supported numerous other studies that demonstrated a greater density of gutta percha with better replication of canal anatomy when heat was applied to various other techniques. $(3,13,15,17,18,19,21,40)$

This study also suggested that a lower temperature setting on the System B Heatsource $^{\mathrm{TM}}$ would be acceptable in producing an equal fill of the root canal system, and likely reduce the possible risk to the health of the periodontium. The temperature settings in this study had no effect on the density of gutta percha. Jung et. al. varied temperature on the plugger in a similar study and found no difference in percentage of gutta percha filled area when using $100^{\circ} \mathrm{C}, 200^{\circ} \mathrm{C}$, and $350^{\circ} \mathrm{C}$ temperatures. (36) It has been suggested that a temperature lower than the recommended $200^{\circ} \mathrm{C}$ temperature makes obturation more difficult in that the gutta percha will not always separate from the down-packed mass of gutta percha after the separation burst. At no time during this study was this observed at any temperature 
setting including $100^{\circ} \mathrm{C}$. The gutta percha appeared to handle the same in every experimental group.

The results of this study suggest that deeper plugger penetration significantly increased the density of gutta percha. This is in agreement with several other studies. (13, $36,37,38,39)$ Jung et.al. found similar results when they compared plugger penetration depths of $2 \mathrm{~mm}$ and $4 \mathrm{~mm}$ short of working length and found a greater percentage of gutta percha filled area when advancing the plugger to $2 \mathrm{~mm}$ short of working length. (36) Yared et.al. studied the sealing ability of vertical compaction and found less apical leakage when taking the plugger closer to the apex. (37) Bowman and Baumgartner found better replication of lateral grooves when the plugger is advanced to $3 \mathrm{~mm}$ from the working length when using the continuous wave of condensation technique. (13)

From the overall results of this study, we can suggest that the safest and most predictable way of using the $\mathrm{CWC}$ obturation technique is at a $100^{\circ} \mathrm{C}$ temperature setting and advancing the plugger to $3 \mathrm{~mm}$ short of working length. However, this was an in-vitro study and should be examined more closely in an in-vivo experimental design. 


\section{CHAPTER V SUMMARY AND CONCLUSIONS}

\section{SUMMARY}

Techniques for obturating root canal anatomy continue to evolve in an attempt to provide the most complete three-dimensional fill possible. This study looked in depth at a gutta percha warm vertical condensation technique that has shown much promise over the last decade in accomplishing just that. The purpose of this study was to quantitatively compare the density of gutta percha under varying temperature settings and depths of plugger penetration when using a System B Heatsource and the Continuous wave of condensation technique.

It was hypothesized that that there would be no difference in the obturation density between the control group (CLC) and the CWC groups. Likewise, it was hypothesized that there would be no difference between the experimental groups (CWC) when varying the temperature and plugger penetration.

The results of this study did not support all of the null hypotheses. There was a significant difference in gutta percha density between the CLC and the CWC techniques. There was no significant difference between the three different temperature settings. However, a significant difference was found when comparing the two depths of plugger penetration. The statistical analysis of the data was performed with a one-way ANOVA and Tukey's HSD tests. 


\section{CONCLUSIONS}

This in-vitro study using acrylic blocks showed that the Continuous wave of condensation technique was superior in obturation density of gutta percha than the cold lateral condensation technique. Varying the temperature setting of the heatsource had no influence on obturation density; however, by positioning the plugger closer to the working length, a more dense gutta percha fill was achieved. 


\section{REFERENCES}

1. Buchanan LS. The continuation wave of condensation technique: a convergence of conceptual and procedural advances in obturation. Dent Today 1994;13:80,82,84-5.

2. Walton RE, Johnson WT. Obturation. In: Walton RE, Torabinejad M. Principles and Practice of Endodontics. Third ed. Philadelphia: W.B. Saunders Co., 2002:246.

3. Reader CM, Himel VT, Germain LP, Hoen MM. Effect of three obturation techniques on the filling of lateral canals and the main canal. J Endod. 1993 Aug;19(8):404-8.

4. Schilder H. Filling root canals in three dimensions. Dent Clin North Am 1967;11:72344.

5. Gutmann JL, Witherspoon DE. Obturation of the cleaned and shaped root canal system. In: Cohen S, Burns RC. Pathways of the pulp. Eighth ed. St Louis: Mosby Inc., 2002:295-99.

6. Ingle JI, Newton CW, West JD, Gutmann JL, Glickman GN, Korzon BH, Martin H. Obturation of the radicular space. In: Ingle JI, Bakland LK. Endodontics. Fifth ed. Hamilton: BC Decker Inc., 2002:599-615.

7. Ruddle C. Cleaning and shaping the root canal system. In: Cohen S, Burns RC. Pathways of the Pulp. Eighth ed. St Louis: Mosby Inc., 2002:235-6.

8. Friedman CM, Sandrik JL, Heuer MA, Rapp, GW. Composition and mechanical properties of gutta percha endodontic points. J Dent Res. 1975; Sept.-Oct.:921-25.

9. Schilder H, Goodman A, Aldrich W. The thermomechanical properties of gutta percha. Part V. Volume changes in the bulk gutta percha as a function of temperature and its relationship to molecular phase treansformation. Oral Surg Oral Med Oral Pathol Oral Radiol Endod. 1985;59:285-296.

10. Ingle JI, Newton CW, West JD, Gutmann JL, Glickman GN, Korzon BH, Martin H. Obturation of the radicular space. In: Ingle JI, Bakland LK. Endodontics. Fifth ed. Hamilton: BC Decker Inc., 2002:575.

11. Buchanan LS. The continuation wave of obturation technique: centered condensation of warm gutta-percha in 12 seconds. Dent Today 1996;15:60-7. 
12. Buchanan LS. Continuous wave of condensation technique. Endod Prac. 1998 Dec;1(4):7-10,13-6,18.

13. Bowman C, Baumgartner J. Gutta-percha obturation of lateral grooves and depressions. J Endod 2002;28:220-3.

14. Blum JY, Machtou P, Micallef JP. Analysis of forces developed during obturation. Wedging effect: Part II. J Endod. 1998 Apr;24(4):223-8.

15. Goldberg F, Artaza LP, De Silvio A. Effectiveness of different obturation techniques in the filling of simulated lateral canals. J Endod 2001;27:362-4.

16. Lea CS, Apicella MJ, Mines P, Yancich PP, Parker MH. Comparison of the obturation density of cold lateral compaction versus warm vertical compaction using the continuous wave of condensation technique. J Endod 2005;31:37-9.

17. Wu MK, van der Sluis LW, Wesselink PR. A preliminary study of the percentage of gutta percha filled area in the apical canal filled with vertically compacted warm gutta percha. Int Endod J. 2002 Jun;35(6):527-35.

18. Jacobson HLJ, Xia T, Baumgartner JC, Marshall JG, Beller WJ. Microbial leakage evaluation of the continuous wave of condensation. J Endod 2002;28:269-71

19. Nelson EA, Liewehr FR, West LA. Increased density of gutta-percha using a controlled heat instrument with lateral condensation. J Endod 2000;26:748-50.

20. Gilhooly RM, Hayes SJ, Bryant ST, Dummer PM. Comparison of cold lateral condensation and a warm multiphase gutta percha technique for obturation curved root canals. Int Endod J. 2000 Sep;33(5):415-20.

21. Wong M, Peters DD, Lorton L. Comparison of gutta-percha filling techniques mechanical compaction, warm vertical, and lateral condensation techniques, part 1. J Endod 1981;7:551-8.

22. ElDeeb ME, Zucker KJ, Messer H. Apical leakage in relation to radiographic density of gutta percha using different obturation techniques. J Endod. 1985 Jan;11(1):25-9.

23. Chugal NM, Clive JM, Spangberg LS. Endodontic infection: some biologic and treatment factors associated with outcome. Oral Surg Oral Med Oral Pathol Oral Radiol Endod 2003; 96:81-90.

24. Benner MD, Peters DD, Grower M, Bernier WE. Evaluation of a new thermoplastic gutta-percha technique using ${ }^{45} \mathrm{Ca}$. J Endod 1981;7:500-8.

25. Larder TC, Prescott AJ, Brayton SM. Gutta-percha: a comparative study of three methods of obturation. J Endod 1976;2:289-94. 
26. Gilhooly RM, Hayes SJ, Bryant ST, Dummer PM. Oral Surg Oral Med Oral Pathol Oral Radiol Endod. 2001 Jan;91(1):89-94.

27. Eriksson A, Albrektsson T, Grane B, McQueen D. Thermal injury to bone. A vitalmicroscopic description of heat effects. Int J Oral Surg. 1982 Apr;11(2):115-21.

28. Eriksson AR, Albrektsson T. J Prosthet Dent. 1983 Jul;50(1):101-7.

29. Fors U, Jonasson E, Berquist A, Berg J. Measurements of the root surface temperature during thermo-mechanical root canal filling in vitro. Int Endod J 1985;18:199-202.

30. Gutmann JL, Rakusin H, Powe R, Bowles WH. Evaluation of heat transfer during root canal obturation with thermoplasticized gutta-percha. Part II. In vivo response to heat levels generated. J Endod 1987;13:441-8.

31. Lee FS, Van Cura JE, BeGole E. A comparison of root surface temperatures using different obturation heat sources. J Endod 1998;24:617-20.

32. Lipski M. Root surface temperature rises during root canal obturation, in vitro, by the continuous wave of condensation technique using System B Heatsource. Oral Surg Oral Med Oral Pathol Oral Radiol Endod 2005;99:505-10.

33. Floren JW, Weller RN, Pashley DH, Kimbrough WF. Changes in root surface temperatures with in vitro use of the System B Heatsource. J Endod. 1999 Sep;25(9):5935.

34. Sweatman TL, Baumgartner JC, Sakaguchi RL. Radicular temperatures associated with thermoplasticized gutta percha. J Endod. 2001 Aug;27(8):512-5.

35. Venturi M, Pasquantonio G, Falconi M, Breschi L. Temperature change within gutta percha induced by the System-B Heatsource. Int Endod J. 2002 Sep;35(9):740-6.

36. Jung IY, Lee SB, Kim ES, Lee CY, Lee SJ. Effect of different temperatures and penetration dnpths of a System B plugger in the filling of artificially created oval canals. Oral Surg Oral Med Oral Pathol Oral Radiol Endod. 2003 Oct;96(4):453-7.

37. Yared GM, BouDagher FE. Influence of plugger penetration on the sealing ability of vertical condensation. J Endod. 1995 Mar;21(3):152-3.

38. Wu MK, Kast'akova A, Wesselink PR. Quality of cold and warm gutta percha filling in oval canals in mandibular premolars. Int Endod J 2001 sep;34(6):485-91.

39. Guess GM, Edwards KR, Yang ML, Iqbal MK, Kim S. Analysis of continuous wave obturation using a single-cone and hybrid technique. J Endod 2003;29:509-12. 
40. Liewehr FR, Kulild JC, Primack PD. Improved density of gutta-percha after warm lateral condensation. J Endod 1993;19:489-91. 


\section{APPENDIX A \\ EXAMINER DATA SHEET}

\begin{tabular}{|c|c|c|c|c|c|}
\hline \multicolumn{6}{|c|}{ Data Collection Sheet } \\
\hline GROUP 1 & $\begin{array}{c}\text { Pre-Obturation } \\
\text { Weight }(\mathbf{g})\end{array}$ & $\begin{array}{c}\text { Post-Obturation } \\
\text { Weight (g) }\end{array}$ & GROUP 2 & $\begin{array}{c}\text { Pre-Obturation } \\
\text { Weight }(\mathrm{g})\end{array}$ & \begin{tabular}{|c|} 
Post-Obturation \\
Weight (g)
\end{tabular} \\
\hline$A$ & 3.8325 & 3.8575 & $A$ & 3.8320 & 3.8719 \\
\hline$B$ & 3.8090 & 3.8355 & $B$ & 3.7987 & 3.8477 \\
\hline C & 3.8312 & 3.8539 & C & 3.8047 & 3.8529 \\
\hline $\mathrm{D}$ & 3.8378 & 3.8579 & $D$ & 3.8226 & 3.8600 \\
\hline $\mathrm{E}$ & 3.8133 & 3.8344 & $E$ & 3.8124 & 3.8673 \\
\hline $\mathrm{F}$ & 3.8004 & 3.8331 & $\mathrm{~F}$ & 3.8208 & 3.8729 \\
\hline$G$ & 3.8086 & 3.8351 & $G$ & 3.8232 & 3.8695 \\
\hline $\mathrm{H}$ & 3.8069 & 3.8328 & $\mathrm{H}$ & 3.8330 & 3.8798 \\
\hline I & 3.8180 & 3.8500 & 1 & 3.8008 & 3.8464 \\
\hline$J$ & 3.8056 & 3.8274 & $\mathrm{~J}$ & 3.7810 & 3.8329 \\
\hline GROUP 3 & $\begin{array}{c}\text { Pre-Obturation } \\
\text { Weight }(\mathrm{g})\end{array}$ & $\begin{array}{c}\text { Post-Obturation } \\
\text { Weight }(\mathrm{g})\end{array}$ & GROUP 4 & $\begin{array}{c}\text { Pre-Obturation } \\
\text { Weight }(\mathrm{g})\end{array}$ & $\begin{array}{c}\text { Post-Obturation } \\
\text { Weight (g) }\end{array}$ \\
\hline$A$ & 3.8058 & 3.8499 & $A$ & 3.7988 & 3.8539 \\
\hline $\mathrm{B}$ & 3.8000 & 3.8432 & $\mathrm{~B}$ & 3.8082 & 3.8602 \\
\hline C & 3.8280 & 3.8759 & C & 3.8122 & 3.8540 \\
\hline $\mathrm{D}$ & 3.8269 & 3.8744 & $\mathrm{D}$ & 3.7914 & 3.8450 \\
\hline$E$ & 3.7950 & 3.8424 & $E$ & 3.8139 & 3.8579 \\
\hline$F$ & 3.8161 & 3.8618 & $\mathrm{~F}$ & 3.7881 & 3.8282 \\
\hline$G$ & 3.8087 & 3.8555 & $G$ & 3.8088 & 3.8538 \\
\hline $\mathrm{H}$ & 3.8282 & 3.8658 & $\mathrm{H}$ & 3.7979 & 3.8473 \\
\hline I & 3.8078 & 3.8548 & I & 3.8160 & 3.8610 \\
\hline $\mathrm{s}$ & 3.8123 & 3.8644 & $\mathrm{~J}$ & 3.8169 & 3.8598 \\
\hline GROUP 5 & $\begin{array}{c}\text { Pre-Obturation } \\
\text { Weight (g) }\end{array}$ & $\begin{array}{c}\text { Post-Obturation } \\
\text { Weight (g) }\end{array}$ & GROUP 6 & $\begin{array}{c}\text { Pre-Obturation } \\
\text { Weight }(\mathrm{g})\end{array}$ & $\begin{array}{c}\text { Post-Obturation } \\
\text { Weight (g) }\end{array}$ \\
\hline$A$ & 3.8090 & 3.8429 & $A$ & 3.7910 & 3.8357 \\
\hline$B$ & 3.8255 & 3.8673 & $\mathrm{~B}$ & 3.8041 & 3.8444 \\
\hline $\mathrm{C}$ & 3.7993 & 3.8479 & C & 3.7885 & 3.8346 \\
\hline $\mathrm{D}$ & 3.8328 & 3.8746 & $\mathrm{D}$ & 3.8275 & 3.8736 \\
\hline$E$ & 3.8071 & 3.8534 & $\mathrm{E}$ & 3.8196 & 3.8688 \\
\hline $\mathrm{F}$ & 3.8196 & 3.8674 & $\mathrm{~F}$ & 3.8004 & 3.8426 \\
\hline $\mathrm{G}$ & 3.7980 & 3.8428 & $\mathrm{G}$ & 3.8286 & 3.8638 \\
\hline $\mathrm{H}$ & 3.8001 & 3.8489 & $\mathrm{H}$ & 3.8127 & 3.8512 \\
\hline 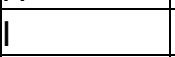 & 3.8142 & 3.8549 & I & 3.8217 & 3.8657 \\
\hline $\mathrm{J}$ & 3.8035 & 3.8476 & $\mathrm{~J}$ & 3.8056 & 3.8451 \\
\hline
\end{tabular}




\begin{tabular}{|l|c|c|}
\hline GROUP 7 & $\begin{array}{c}\text { Pre-Obturation } \\
\text { Weight } \mathbf{( g )}\end{array}$ & $\begin{array}{c}\text { Post-Obturation } \\
\text { Weight } \mathbf{( g )}\end{array}$ \\
\hline A & 3.8072 & 3.8515 \\
\hline B & 3.8227 & 3.8644 \\
\hline E & 3.8159 & 3.8519 \\
\hline D & 3.8184 & 3.8586 \\
\hline E & 3.7990 & 3.8427 \\
\hline F & 3.8000 & 3.8450 \\
\hline G & 3.8163 & 3.8613 \\
\hline H & 3.7972 & 3.8400 \\
\hline & 3.8103 & 3.8562 \\
\hline J & 3.8139 & 3.8497 \\
\end{tabular}




\section{APPENDIX B STATISTICAL RESULTS}

\begin{tabular}{|c|c|c|c|c|c|}
\hline \multicolumn{6}{|c|}{ Average Mass of Gutta Percha } \\
\hline GROUP 1 & Post - Pre & GROUP 2 & Post - Pre & GROUP 3 & Post - Pre \\
\hline$A$ & 0.0250 & A & 0.0399 & A & 0.0441 \\
\hline $\mathrm{B}$ & 0.0265 & $B$ & 0.0490 & $B$ & 0.0432 \\
\hline C & 0.0227 & C & 0.0482 & C & 0.0479 \\
\hline $\mathrm{D}$ & 0.0201 & D & 0.0374 & D & 0.0475 \\
\hline $\mathrm{E}$ & 0.0211 & $\mathrm{E}$ & 0.0549 & $\mathrm{E}$ & 0.0474 \\
\hline$F$ & 0.0327 & $\mathrm{~F}$ & 0.0521 & $\mathrm{~F}$ & 0.0457 \\
\hline$G$ & 0.0265 & $G$ & 0.0463 & $G$ & 0.0468 \\
\hline $\mathrm{H}$ & 0.0259 & $\mathrm{H}$ & 0.0468 & $\mathrm{H}$ & 0.0376 \\
\hline 1 & 0.0320 & I & 0.0456 & I & 0.0470 \\
\hline $\mathrm{J}$ & 0.0218 & $J$ & 0.0519 & $J$ & 0.0521 \\
\hline Mean & 0.02543 & Mean & 0.04721 & Mean & 0.04593 \\
\hline Std. Dev & 0.00430 & Std. Dev & 0.00540 & Std. Dev & 0.00378 \\
\hline GROUP 4 & Post - Pre & GROUP 5 & Post - Pre & GROUP 6 & Post - Pre \\
\hline$A$ & 0.0551 & $A$ & 0.0339 & $A$ & 0.0447 \\
\hline$B$ & 0.0520 & $B$ & 0.0418 & $\mathrm{~B}$ & 0.0403 \\
\hline $\mathrm{C}$ & 0.0418 & C & 0.0486 & $\mathrm{C}$ & 0.0461 \\
\hline$D$ & 0.0536 & $\mathrm{D}$ & 0.0418 & $D$ & 0.0461 \\
\hline $\mathrm{E}$ & 0.0440 & $\mathrm{E}$ & 0.0463 & $\mathrm{E}$ & 0.0492 \\
\hline$F$ & 0.0401 & $\mathrm{~F}$ & 0.0478 & $F$ & 0.0422 \\
\hline $\mathrm{G}$ & 0.0450 & $G$ & 0.0448 & $G$ & 0.0352 \\
\hline $\mathrm{H}$ & 0.0494 & $\mathrm{H}$ & 0.0488 & $\mathrm{H}$ & 0.0385 \\
\hline 1 & 0.0450 & I & 0.0407 & 1 & 0.0440 \\
\hline \begin{tabular}{|l|}
$J$ \\
\end{tabular} & 0.0429 & $\mathrm{~J}$ & 0.0441 & $J$ & 0.0395 \\
\hline Mean & 0.04689 & Mean & 0.04386 & Mean & 0.04258 \\
\hline Std. Dev & 0.00525 & Std. Dev & 0.00456 & Std. Dev & 0.00423 \\
\hline GROUP 7 & Post - Pre & & & & \\
\hline A & 0.0443 & & & & \\
\hline$B$ & 0.0417 & & & & \\
\hline$C$ & 0.0360 & & & & \\
\hline $\mathrm{D}$ & 0.0402 & & & & \\
\hline $\mathrm{E}$ & 0.0437 & & & & \\
\hline$F$ & 0.0450 & & & & \\
\hline$G$ & 0.0450 & & & & \\
\hline $\mathrm{H}$ & 0.0428 & & & & \\
\hline 1 & 0.0459 & & & & \\
\hline$J$ & 0.0358 & & & & \\
\hline Mean & 0.04204 & & & & \\
\hline Std. Dev & 0.00365 & & & & \\
\hline
\end{tabular}




\begin{tabular}{|c|c|c|c|c|c|c|c|c|}
\hline \multicolumn{8}{|c|}{ DATA TABLE } & \multirow[b]{12}{*}{ TOTALS } \\
\hline Block & Group 1 & Group 2 & Group 3 & Group 4 & Group 5 & Group 6 & Group 7 & \\
\hline A & 0.02500 & 0.03990 & 0.04410 & 0.05510 & 0.03390 & 0.04470 & 0.04430 & \\
\hline$B$ & 0.02650 & 0.04900 & 0.04320 & 0.05200 & 0.04180 & 0.04030 & 0.04170 & \\
\hline$C$ & 0.02270 & 0.04820 & 0.04790 & 0.04180 & 0.04860 & 0.04610 & 0.03600 & \\
\hline$D$ & 0.02010 & 0.03740 & 0.04750 & 0.05360 & 0.04180 & 0.04610 & 0.04020 & \\
\hline E & 0.02110 & 0.05490 & 0.04740 & 0.04400 & 0.04630 & 0.04920 & 0.04370 & \\
\hline$F$ & 0.03270 & 0.05210 & 0.04570 & 0.04010 & 0.04780 & 0.04220 & 0.04500 & \\
\hline$G$ & 0.02650 & 0.04630 & 0.04680 & 0.04500 & 0.04480 & 0.03520 & 0.04500 & \\
\hline $\mathrm{H}$ & 0.02590 & 0.04680 & 0.03760 & 0.04940 & 0.04880 & 0.03850 & 0.04280 & \\
\hline I & 0.03200 & 0.04560 & 0.04700 & 0.04500 & 0.04070 & 0.04400 & 0.04590 & \\
\hline $\mathrm{J}$ & 0.02180 & 0.05190 & 0.05210 & 0.04290 & 0.04410 & 0.03950 & 0.03580 & \\
\hline SUM & 0.25430 & 0.47210 & 0.45930 & 0.46890 & 0.43860 & 0.42580 & 0.42040 & 2.93940 \\
\hline mean & 0.02543 & 0.04721 & 0.04593 & 0.04689 & 0.04386 & 0.04258 & 0.04204 & 0.04199 \\
\hline \multicolumn{6}{|c|}{ STATISTICAL PARAMETERS } & & & \\
\hline \multicolumn{4}{|c|}{ significance level (alpha) $=$} & \multicolumn{2}{|c|}{0.05} & & & \\
\hline \multicolumn{4}{|c|}{ Number of groups $(k)=$} & \multicolumn{2}{|c|}{7} & & & \\
\hline \multicolumn{4}{|c|}{ total number of observations $(\mathrm{N})=$} & \multicolumn{2}{|c|}{70} & & & \\
\hline \multicolumn{4}{|c|}{ Number of observations per group $(n)=$} & \multicolumn{2}{|c|}{10} & & & \\
\hline \multirow{2}{*}{\multicolumn{4}{|c|}{$\begin{array}{r}\text { q from Appendix C }= \\
\text { HSD AT } 0.95 \%=\end{array}$}} & \multicolumn{2}{|c|}{4.30} & & & \\
\hline & & & & \multicolumn{2}{|c|}{0.006114291} & & & \\
\hline \multicolumn{5}{|c|}{ ANOVA TABLE } & & & & \\
\hline \begin{tabular}{|l} 
Source of \\
variation
\end{tabular} & $\begin{array}{l}\text { Sum of } \\
\text { Squares }\end{array}$ & df & \begin{tabular}{|c|} 
Mean \\
Squares \\
\end{tabular} & F ratio & & & & \\
\hline Between & 0.003449 & 6 & 0.000575 & 28.4276 & & & & \\
\hline Within & 0.001274 & 63 & 0.000020 & & & & & \\
\hline Total & 0.004722 & 69 & & & & & & \\
\hline \multicolumn{8}{|c|}{\begin{tabular}{|c|} 
ANOVA SUMMARY \\
\end{tabular}} & \\
\hline \multicolumn{8}{|c|}{$\begin{array}{l}\text { From the table above it can be determined that the } F \text { ratio is greater than the tabulated } \\
\text { F value of } F(6,63)=2.24 \text {. This indicates that at least one of the means is significantly } \\
\text { different from the others. To determine the statistically different means, a Tukey's HSD } \\
\text { was performed. }\end{array}$} & \\
\hline \multicolumn{7}{|c|}{$\begin{array}{l}\text { Tukey's HSD (Honestly Significant Difference) test } \\
\text { Tukey's HSD test was used to determine if the means from groups } 2-7 \\
\text { were equal to group } 1 \text { by comparing the HSD with the difference of means } \\
\end{array}$} & & \\
\hline \multicolumn{7}{|c|}{ Comparison to Group 1} & & \\
\hline Group & 2 & 3 & 4 & 5 & 6 & 7 & & \\
\hline Diff of means & 0.02178 & 0.0205 & 0.02146 & 0.01843 & 0.01715 & 0.01661 & & \\
\hline $\begin{array}{l}\text { Sig. Diff. at } \\
0.05 \text { sig level }\end{array}$ & YES & YES & YES & YES & YES & YES & & \\
\hline
\end{tabular}




\begin{tabular}{|c|c|c|c|c|c|c|c|c|}
\hline \multicolumn{8}{|c|}{ DATA TABLE FOR PLUGGER DEPTHS } & \multirow[b]{12}{*}{ TOTALS } \\
\hline Block & $\mathbf{x}$ & \multicolumn{3}{|c|}{ Group 2-4 } & \multicolumn{3}{|c|}{ Group 5-7 } & \\
\hline A & $x$ & 0.03990 & 0.04410 & 0.05510 & 0.03390 & 0.04470 & 0.04430 & \\
\hline $\mathrm{B}$ & $x$ & 0.04900 & 0.04320 & 0.05200 & 0.04180 & 0.04030 & 0.04170 & \\
\hline C & $x$ & 0.04820 & 0.04790 & 0.04180 & 0.04860 & 0.04610 & 0.03600 & \\
\hline $\mathrm{D}$ & $x$ & 0.03740 & 0.04750 & 0.05360 & 0.04180 & 0.04610 & 0.04020 & \\
\hline E & $x$ & 0.05490 & 0.04740 & 0.04400 & 0.04630 & 0.04920 & 0.04370 & \\
\hline$F$ & $x$ & 0.05210 & 0.04570 & 0.04010 & 0.04780 & 0.04220 & 0.04500 & \\
\hline$G$ & $x$ & 0.04630 & 0.04680 & 0.04500 & 0.04480 & 0.03520 & 0.04500 & \\
\hline $\mathrm{H}$ & $x$ & 0.04680 & 0.03760 & 0.04940 & 0.04880 & 0.03850 & 0.04280 & \\
\hline 1 & $x$ & 0.04560 & 0.04700 & 0.04500 & 0.04070 & 0.04400 & 0.04590 & \\
\hline $\mathrm{J}$ & $x$ & 0.05190 & 0.05210 & 0.04290 & 0.04410 & 0.03950 & 0.03580 & \\
\hline SUM & $x$ & & & 1.40030 & & & 1.28480 & 2.68510 \\
\hline mean & $x$ & & & 0.04668 & & & 0.04283 & 0.04475 \\
\hline \multicolumn{6}{|c|}{ STATISTICAL PARAMETERS } & & & \\
\hline \multicolumn{4}{|c|}{ significance level (alpha) $=$} & \multicolumn{2}{|c|}{0.05} & & & \\
\hline \multicolumn{4}{|c|}{ Number of groups $(k)=$} & \multicolumn{2}{|c|}{2} & & & \\
\hline \multicolumn{4}{|c|}{ total number of observations $(\mathrm{N})=$} & \multicolumn{2}{|c|}{60} & & & \\
\hline \multicolumn{4}{|c|}{ Number of observations per group $(n)=$} & \multicolumn{2}{|c|}{30} & & & \\
\hline \multicolumn{4}{|c|}{$q$ from Appendix C $=$} & \multicolumn{2}{|c|}{2.83} & & & \\
\hline \multicolumn{4}{|c|}{ HSD AT $0.95 \%=$} & \multicolumn{2}{|c|}{0.002284273} & & & \\
\hline \multicolumn{5}{|c|}{ ANOVA TABLE } & & & & \\
\hline $\begin{array}{l}\text { Source of } \\
\text { variation }\end{array}$ & $\begin{array}{c}\text { Sum of } \\
\text { Squares }\end{array}$ & df & $\begin{array}{c}\text { Mean } \\
\text { Squares }\end{array}$ & F ratio & & & & \\
\hline Between & 0.000222 & 1 & 0.000222 & 11.37545 & & & & \\
\hline Within & 0.001134 & 58 & 0.000020 & & & & & \\
\hline Total & 0.001356 & 59 & & & & & & \\
\hline \multicolumn{8}{|c|}{ ANOVA SUMMARY } & \\
\hline \multicolumn{8}{|c|}{$\begin{array}{l}\text { From the table above it can be determined that the } F \text { ratio is greater than the tabulated } F \\
\text { value of } F(1,58)=3.99 \text {. This indicates that at least one of the means is significantly } \\
\text { different from the others. To determine the statistically different means, a Tukey's HSD } \\
\text { was performed. }\end{array}$} & \\
\hline \multicolumn{7}{|c|}{$\begin{array}{l}\text { Tukey's HSD (honestly significant difference) test } \\
\text { Tukey's HSD test was used to determine if the means from groups } 2-4 \\
\text { were equal to groups } 5-7 \text { by comparing the HSD with the difference of means }\end{array}$} & & \\
\hline \multicolumn{2}{|c|}{ Comparison to Group 2,3,4 } & & & & & & & \\
\hline Group & $5,6,7$ & & & & & & & \\
\hline Diff of means & 0.00385 & & & & & & & \\
\hline $\begin{array}{l}\text { Sig Difference } \\
\text { at } 0.05 \text { sig level }\end{array}$ & YES & & & & & & & \\
\hline
\end{tabular}




\begin{tabular}{|c|c|c|c|c|c|c|c|c|}
\hline \multicolumn{8}{|c|}{ DATA TABLE FOR EXPERIMENTAL GROUPS } & \multirow[b]{12}{*}{ TOTALS } \\
\hline Block & Group 1 & Group 2 & Group 3 & Group 4 & Group 5 & Group 6 & Group 7 & \\
\hline A & $x$ & 0.03990 & 0.04410 & 0.05510 & 0.03390 & 0.04470 & 0.04430 & \\
\hline $\mathrm{B}$ & $x$ & 0.04900 & 0.04320 & 0.05200 & 0.04180 & 0.04030 & 0.04170 & \\
\hline C & $x$ & 0.04820 & 0.04790 & 0.04180 & 0.04860 & 0.04610 & 0.03600 & \\
\hline$D$ & $x$ & 0.03740 & 0.04750 & 0.05360 & 0.04180 & 0.04610 & 0.04020 & \\
\hline$E$ & $x$ & 0.05490 & 0.04740 & 0.04400 & 0.04630 & 0.04920 & 0.04370 & \\
\hline$F$ & $x$ & 0.05210 & 0.04570 & 0.04010 & 0.04780 & 0.04220 & 0.04500 & \\
\hline$G$ & $x$ & 0.04630 & 0.04680 & 0.04500 & 0.04480 & 0.03520 & 0.04500 & \\
\hline $\mathrm{H}$ & $x$ & 0.04680 & 0.03760 & 0.04940 & 0.04880 & 0.03850 & 0.04280 & \\
\hline 1 & $x$ & 0.04560 & 0.04700 & 0.04500 & 0.04070 & 0.04400 & 0.04590 & \\
\hline $\mathrm{J}$ & $x$ & 0.05190 & 0.05210 & 0.04290 & 0.04410 & 0.03950 & 0.03580 & \\
\hline SUM & $x$ & 0.47210 & 0.45930 & 0.46890 & 0.43860 & 0.42580 & 0.42040 & 2.68510 \\
\hline mean & $x$ & 0.04721 & 0.04593 & 0.04689 & 0.04386 & 0.04258 & 0.04204 & 0.04475 \\
\hline \multicolumn{6}{|c|}{ STATISTICAL PARAMETERS } & & & \\
\hline \multicolumn{6}{|c|}{ significance level (alpha) = } & & & \\
\hline \multirow{2}{*}{\multicolumn{4}{|c|}{ Number of groups $(k)=$}} & \multicolumn{2}{|c|}{6} & & & \\
\hline \multirow{2}{*}{\multicolumn{4}{|c|}{ total number of observations $(\mathrm{N})=$}} & \multicolumn{2}{|c|}{60} & & & \\
\hline & & & & \multicolumn{2}{|c|}{10} & & & \\
\hline \multicolumn{4}{|c|}{ q from Appendix C = } & \multicolumn{2}{|c|}{4.18} & & & \\
\hline \multicolumn{4}{|c|}{ HSD AT $0.95 \%=$} & \multicolumn{2}{|c|}{0.005985614} & & & \\
\hline \multicolumn{5}{|c|}{ ANOVA TABLE } & & & & \\
\hline $\begin{array}{l}\text { Source of } \\
\text { variation }\end{array}$ & \begin{tabular}{|c|} 
Sum of \\
Squares
\end{tabular} & df & $\begin{array}{c}\text { Mean } \\
\text { Squares }\end{array}$ & F ratio & & & & \\
\hline Between & 0.000249 & 5 & 0.000050 & 2.425593 & & & & \\
\hline Within & 0.001107 & 54 & 0.000021 & & & & & \\
\hline Total & 0.001356 & 59 & & & & & & \\
\hline \multicolumn{8}{|c|}{ ANOVA SUMMARY } & \\
\hline \multicolumn{8}{|c|}{$\begin{array}{l}\text { From the table above, it can be determined that the } F \text { ratio may be greater than the } \\
\text { tabulated } F \text { value of } F(5,54)=2.37-2.45 \text {. This indicates that there may be one of the } \\
\text { means that is significantly different from the others. }\end{array}$} & \\
\hline \multicolumn{7}{|c|}{$\begin{array}{l}\text { Tukey's HSD (honestly significant difference) test } \\
\text { Tukey's HSD test was used to test the hypothesis that all } \\
\text { possible pairs of means are equal }\end{array}$} & & \\
\hline Group & $2-3$ & $2-4$ & $2-5$ & $2-6$ & $2-7$ & $3-4$ & & \\
\hline Diff of means & 0.00128 & \begin{tabular}{|l|}
0.00032 \\
\end{tabular} & 0.00335 & 0.00463 & \begin{tabular}{|l|}
0.00517 \\
\end{tabular} & 0.00096 & & \\
\hline $\begin{array}{l}\text { Sig Difference } \\
\text { at } 0.05 \text { sig level }\end{array}$ & NO & NO & NO & NO & NO & NO & & \\
\hline
\end{tabular}




\begin{tabular}{|c|c|c|c|c|c|c|}
\hline Group & $3-5$ & $3-6$ & $3-7$ & $4-5$ & $4-6$ & $4-7$ \\
\hline Diff of means & 0.00207 & 0.00335 & 0.00389 & 0.00303 & 0.00431 & 0.00485 \\
\hline $\begin{array}{l}\text { Sig Difference } \\
\text { at } 0.05 \text { sig level }\end{array}$ & NO & NO & NO & NO & NO & NO \\
\hline & & & & & & \\
\hline Group & $5-6$ & $5-7$ & $6-7$ & & & \\
\hline Diff of means & 0.00128 & 0.00182 & 0.00054 & & & \\
\hline $\begin{array}{l}\text { Sig Difference } \\
\text { at } 0.05 \text { sig level }\end{array}$ & NO & NO & NO & & & \\
\hline
\end{tabular}




\section{CURRICULMN VITAE}

\section{JAMIE MICHELE DAY, D.D.S.}

Born: December 13, 1978

\section{Education}

- 2004-2006, Master of Science in Endodontics

West Virginia University School of Dentistry, Morgantown WV

- 2000-2004, Doctor of Dental Surgery

West Virginia University School of Dentistry, Morgantown WV

- 1997-2000, Bachelor of Arts in Biology

West Virginia University, Morgantown WV

- 1993-1997, High School Diploma

Lewis County High School, Weston WV

\section{Awards and Distinctions}

- West Virginia Dental Scholarship 2002-2004

- Omicron Kappa Upsilon Alumni Member inducted 2004

- Quintessence Award in Restorative Dentistry 2004

- Omicron Kappa Upsilon William S. Kramer Award of Excellence 2003

- Dr. and Mrs. Mohssen Ghalichebaf Cleft Lip and Palate Scholarship 2002-2003

- Omicron Kappa Upsilon Basic Science Award 2002

\section{Work Experience}

- Associate Dentist for Dr. Diana Frum 2004-2006

- Conservation Biologist with the USDA, Natural Resource Conservation Service 2000

- Lifeguard and swimming instructor at WVU Jackson's Mill 1998-1999 